\title{
Depside and Depsidone Synthesis in Lichenized Fungi Comes into Focus through a Genome-Wide Comparison of the Olivetoric Acid and Physodic Acid Chemotypes of Pseudevernia furfuracea
}

\author{
Garima Singh ${ }^{1,2, *}$, Daniele Armaleo ${ }^{3}(0)$, Francesco Dal Grande ${ }^{1,2}$ and Imke Schmitt ${ }^{1,2,4}$ \\ 1 Senckenberg Biodiversity and Climate Research Centre (SBiK-F), 60325 Frankfurt am Main, Germany; \\ francesco.dalgrande@senckenberg.de (F.D.G.); imke.schmitt@senckenberg.de (I.S.) \\ 2 LOEWE Center for Translational Biodiversity Genomics (TBG), 60325 Frankfurt am Main, Germany \\ 3 Department of Biology, Duke University, Durham, NC 27708, USA; darmaleo@duke.edu \\ 4 Fachbereich Biowissenschaften, Institut für Ökologie, Evolution und Diversität, Goethe Universität Frankfurt, \\ 60438 Frankfurt am Main, Germany \\ * Correspondence: garima.singh@senckenberg.de
}

\section{check for} updates

Citation: Singh, G.; Armaleo, D.; Dal Grande, F.; Schmitt, I. Depside and Depsidone Synthesis in Lichenized Fungi Comes into Focus through a Genome-Wide Comparison of the Olivetoric Acid and Physodic Acid Chemotypes of Pseudevernia furfuracea. Biomolecules 2021, 11, 1445. https:// doi.org/10.3390/biom11101445

Academic Editors: Mark Harrison and Vladimir N. Uversky

Received: 7 September 2021

Accepted: 28 September 2021

Published: 2 October 2021

Publisher's Note: MDPI stays neutral with regard to jurisdictional claims in published maps and institutional affiliations.

Copyright: (c) 2021 by the authors. Licensee MDPI, Basel, Switzerland. This article is an open access article distributed under the terms and conditions of the Creative Commons Attribution (CC BY) license (https:// creativecommons.org/licenses/by/ $4.0 /)$.

\begin{abstract}
Primary biosynthetic enzymes involved in the synthesis of lichen polyphenolic compounds depsides and depsidones are non-reducing polyketide synthases (NR-PKSs), and cytochrome P450s. However, for most depsides and depsidones the corresponding PKSs are unknown. Additionally, in non-lichenized fungi specific fatty acid synthases (FASs) provide starters to the PKSs. Yet, the presence of such FASs in lichenized fungi remains to be investigated. Here we implement comparative genomics and metatranscriptomics to identify the most likely PKS and FASs for olivetoric acid and physodic acid biosynthesis, the primary depside and depsidone defining the two chemotypes of the lichen Pseudevernia furfuracea. We propose that the gene cluster PF33-1_006185, found in both chemotypes, is the most likely candidate for the olivetoric acid and physodic acid biosynthesis. This is the first study to identify the gene cluster and the FAS likely responsible for olivetoric acid and physodic acid biosynthesis in a lichenized fungus. Our findings suggest that gene regulation and other epigenetic factors determine whether the mycobiont produces the depside or the depsidone, providing the first direct indication that chemotype diversity in lichens can arise through regulatory and not only through genetic diversity. Combining these results and existing literature, we propose a detailed scheme for depside/depsidone synthesis.
\end{abstract}

Keywords: lichen-forming fungi; natural products; secondary metabolites; orsellinic acid derivatives; chemosyndrome; biosynthetic gene clusters; fatty acid synthases; cytochrome P450; PKSs

\section{Introduction}

Depsides and depsidones, the polyphenolic polyketides mostly synthesized by lichenized fungi, are of significant pharmaceutical interest [1-3]. Depsides consist of two or sometimes three orcinol or $\beta$-orcinol-derived aromatic rings joined by ester linkages; depsidones have an additional ether linkage between the rings (Figure 1). Additionally, depending on the starters used by the polyketide synthases (PKSs) assembling their backbones, 3-7 carbon side chains may be linked to the 6 and $6^{\prime}$ carbons of the orcinol-derived rings. Together with other ring modifications, side chains constitute the distinguishing features of different depsides and depsidones. Although chemical proposals for depside and depsidone biosynthesis go back many decades $[4,5]$, the precise enzymatic steps of depside and depsidone synthesis still need to be elucidated. Furthermore, for most of the depside and depsidone metabolites of lichens, the corresponding genes remain uncharacterized. This is because fungi contain far more biosynthetic genes than known compounds [6,7]. One way to connect metabolites to the associated genes is to identify all the genomic regions 
with putative biosynthetic genes and narrow down this selection to the most likely gene cluster based on phylogenetic evidence, and other cluster information, such as the presence of particular genes. Long-read sequencing technologies and the resulting high-quality contiguous genome assemblies have greatly facilitated this process.

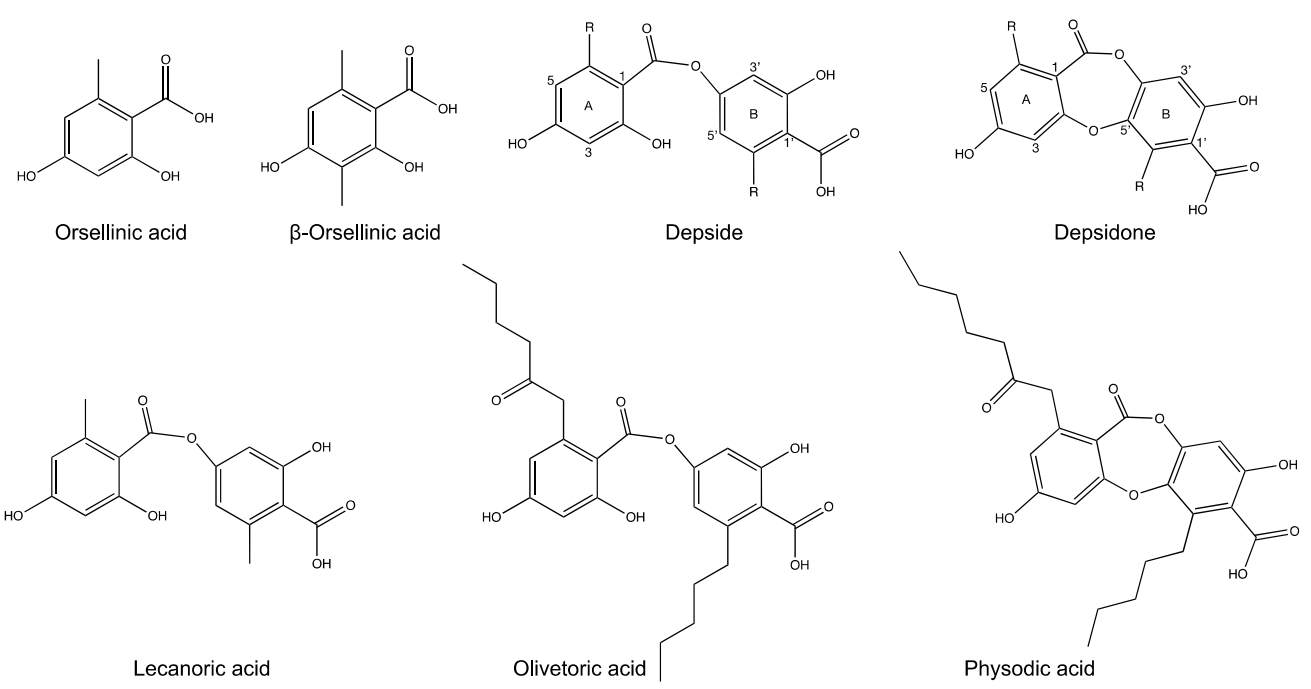

Figure 1. Chemical structures and nomenclature. Top row: monocyclic precursors and generic structures of depsides and depsidones; letters and numbers apply to all depsides and depsidones. Bottom row: the main compounds discussed here.

Fungal type I PKSs are iterative and consist of several domains with defined functions. Non-reducing, type I PKSs (NR-PKSs) contain KS (keto-synthase), AT (acyltransferase), PT (product template), ACP (acyl carrier protein), and TE (thioesterase) domains [8,9]. While NR-PKSs have long been known to assemble and fold the carbon backbones of depsides and depsidones, their specific roles in linking the rings have come to light only recently. A single PKS catalyzes the formation and dimerization of phenolic rings to produce a depside $[10,11]$ while a cytochrome P450 is needed to catalyze the formation of an ether bond between the depside rings to produce a depsidone [10]. The PKS constructs and esterifies the two different rings using two ACP domains [12]. The genes for PKS and cytochrome P450 (CytP450) are closely linked within the same biosynthetic gene cluster (BGC). BGCs contain several genes involved in the synthesis of a compound, e.g., the core biosynthetic PKS, redox enzymes, transporters, etc. A BGC is named based on the type of backbone enzyme encoded by the core gene, e.g., a PKS cluster, a terpene cluster, etc.

Studies with non-lichen-forming fungi indicate that specific fatty acid synthases (metabolite FASs) also play significant roles in metabolite synthesis by providing the appropriate acyl chain starters to some PKSs [13-15]. Inactivation of metabolite FASs may inhibit secondary metabolite synthesis even when the corresponding PKS and BGC remain functional [16]. However, the role of metabolite FAS in providing the starters for depsides and depsidones in lichen-forming fungi has not been investigated, despite the fact that the primary starters of orcinol depsides and depsidones are, besides the $\mathrm{C} 2$ doublet from acetyl-CoA, C4, C6, and C8 acyl chains [17]. After polyketide assembly and cyclization, the resulting ring side chains will respectively be 1, 3, 5, or 7 carbons long. Recently and coincidentally, the NR-PKS from the lichen Pseudevernia furfuracea that we identify in this work as the likely producer of the depside olivetoric acid was reported to produce the depside lecanoric acid when heterologously expressed in yeast [18]. Yet in nature lecanoric acid has never been reported from P. furfuracea. The difference between lecanoric and olivetoric acid is that the former has a methyl group on each ring whereas the latter has a $\mathrm{C5}$ side chain on one ring and a C7 side chain on the other (Figure 1). We integrate this apparent discrepancy with other data to highlight the central role that lichen short-chain FASs are likely to play in providing the side chains common in orcinol depsides and depsidones and 
propose a scheme for depside/depsidone biosynthesis. Understanding the mechanism of depside/depsidone synthesis can help to unravel the evolution and diversification of this compound class in lichens and contribute to improving the biotechnological production of pharmaceutically valuable natural products from uncultivable lichens.

In this study, we implemented a long-read-based genomic approach to better understand the mechanism of depside/depsidone synthesis in lichen-forming fungi. We chose Pseudevernia furfuracea as our study system because it is a textbook example of chemosyndrome variation in a lichen-forming fungus [19-21]. This lichen consists of two naturally occurring chemotypes, one synthesizing an orcinol depside (olivetoric acid), and the other the corresponding depsidone (physodic acid), and thus constitutes an ideal model to study depside/depsidone synthesis and the causes of chemotype diversity. Both chemotypes also synthesize the B-orcinol depside atranorin, common in many lichens. Specifically, we aim to answer the following questions: (1) Do the depside and the depsidone producer contain the same number of BGCs? (2) Which BGC/s are likely responsible for the production of the depside olivetoric acid and the depsidone physodic acid in P. furfuracea chemotypes? (3) Are there homologs of metabolite FASs in the lichen-forming fungal genome? We then integrate the available data to provide a detailed scheme of orcinol depside/depsidone biosynthesis in lichens.

\section{Materials and Methods}

\subsection{Identification of Chemotypes}

We used high-performance liquid chromatography (HPLC) to investigate the chemotypes of $P$. furfuracea. We collected several samples of $P$. furfuracea and performed HPLC analysis using the protocol from Feige et al. [22] and Benatti et al. [23]. First, small thallus pieces were extracted for $1 \mathrm{~h}$ at room temperature in $200 \mu \mathrm{L}$ of methanol. From this, $150 \mu \mathrm{L}$ of the extract of each sample was centrifuged $1 \mathrm{~min}$ at $800 \mathrm{rpm}$ through a Pall Acroprep Advance $0.2 \mu \mathrm{m}$ polytetrafluoroethylene filter plate and then diluted 10-fold with methanol. The samples were analyzed on an Agilent 1260 quaternary system with a quaternary pump, an incorporated degasser, and using an Agilent Poroshell 120 EC-C18 column $(2.7 \mu \mathrm{m}$, $3.0 \times 50 \mathrm{~mm}$ ). Substances were separated at $30^{\circ} \mathrm{C}$ using two solvent systems and a flow rate of $1.4 \mathrm{~mL} / \mathrm{min}$. Solvent A is Aqua Bidest, $30 \%$ methanol, and $0.0658 \%$ trifluoroacetic acid, and solvent B is $100 \%$ methanol. The HPLC system was equilibrated to solvent A for $2 \mathrm{~min}$ and $2 \mu \mathrm{L}$ of extract was injected automatically after a needle wash. The runs continued isocratically for $0.18 \mathrm{~min}$, solvent B was increased to $58 \%$ within $5 \mathrm{~min}$, then increased to $100 \%$ within the next $5 \mathrm{~min}$ and isocratically maintained for $0.82 \mathrm{~min}$. The runs ended with solvent A being increased back to $100 \%$ within 0.5 min. After the run, the column was flushed for two minutes before the next run. Compounds were detected with a diode array detector (DAD) at 210, 254, 280, and $310 \mathrm{~nm}$. The retention times and spectra ( $\lambda=190-650 \mathrm{~nm}$ with 2-nm steps) were compared against a library of authentic products derived under identical conditions using the Agilent OpenLAB CDS ChemStation software. We then selected one sample of each chemotype for genome sequencing (Supplementary Table S1).

\subsection{DNA Extraction and Genome Sequencing}

Lichen thalli were thoroughly washed with sterile water and checked under the stereomicroscope for the presence of possible contamination. DNA was extracted from both samples using a CTAB-based method [24]. DNA concentration was measured with a Qubit fluorometer (dsDNA BR, Invitrogen). $4.1 \mu \mathrm{g}$ and $7.4 \mu \mathrm{g}$ DNA for the olivetoric acid and physodic acid chemotype, respectively, was sent to Novogene Hong Kong for PacBio library preparation and sequencing on two separate SMRT cells, one for each chemotype.

\subsection{Genome Assembly and Annotation}

PacBio metagenomes were assembled using the long-read based assembler metaFlye v2.3.1 [25]. Reads were filtered for length ( $>2000 \mathrm{bp}$ fragments only) and assembly was 
optimized for minimal read overlap of $3 \mathrm{~kb}$, and an estimated combined metagenome size of $120 \mathrm{Mb}$. The assembled genome was polished twice using the software Arrow from the SMRTlink suite v. 5.0.1.9585 [26]. The resulting contigs were then scaffolded with SSPACELongRead v1.1 [27]. Ascomycota contigs were then identified in the metagenomic assembly using Diamond v0.8.34.96 BLASTx using the more-sensitive mode for longer sequences and a default e-value cut-off of 0.001 against a custom database [7]. The Diamond results were then parsed in MEGAN v.6.7.7 [28], using Max Expected set to 1E-10 and the weighted lowest common ancestor (LCA) algorithm. All contigs assigned to Ascomycota were exported to represent the P. furfuracea mycobiont. Assembly indicators such as number of contigs, total length, and N50 were assessed with Assemblathon v2 [29] (Table 1). Genome completeness was estimated based on evolutionarily-informed expectations of gene content with BUSCO v.4.0 (Benchmarking Universal Single-Copy Orthologs) [30]. The genomes are deposited in GenBank under accessions JAIUPT000000000 (olivetoric acid chemotype) and JAIUPS000000000 (physodic acid chemotype).

Table 1. Genome statistics and GB accession numbers of the two chemotypes of P. furfuracea.

\begin{tabular}{|c|c|c|c|}
\hline & & Physodic Acid Chemotype & Olivetoric Acid Chemotype \\
\hline \multirow{4}{*}{ Sequencing Report } & Genome accession nos. & JAIUPS000000000 & JAIUPT000000000 \\
\hline & Subreads bases $(\mathrm{Gb})$ & 8.182 & 8.122 \\
\hline & Average subreads length & 9563 & 9325 \\
\hline & N50 raw reads & 12855 & 12479 \\
\hline \multirow{7}{*}{ Assembly Stats } & \# scaffolds & 104 & 53 \\
\hline & CDS & 11199 & 10480 \\
\hline & size $(\mathrm{Mb})$ & 34.2 & 37.3 \\
\hline & N50 & $632 \mathrm{~kb}$ & $1.6 \mathrm{Mb}$ \\
\hline & \% completeness & 96 & 92 \\
\hline & homologous clusters & \multicolumn{2}{|c|}{51} \\
\hline & chemotype specific clusters & 5 & 1 \\
\hline \multirow{8}{*}{ BGCs Summary } & R-PKSs & 19 & 14 \\
\hline & NR-PKSs & 4 & 4 \\
\hline & hybrid & 10 & 8 \\
\hline & T3-PKS & 1 & 1 \\
\hline & NRPS & 4 & 4 \\
\hline & NRPS-like & 10 & 12 \\
\hline & Terpenes & 6 & $\underline{6}$ \\
\hline & indole & 2 & 2 \\
\hline
\end{tabular}

Genome statistics and SRA accession numbers of the two chemotypes of P. furfuracea and biosynthetic gene clusters (BGCs) as predicted by antiSMASH v5.0. PKS = polyketide synthase, R-PKS = reducing PKS, NR-PKS = non-reducing PKS, T3 PKS = type III PKS, and NRPS = non-ribosomal peptide synthetase.

\subsection{Identification and Annotations of Biosynthetic Gene Clusters}

Gene prediction, functional annotation, and prediction of BGCs in both P. furfuracea assemblies were performed with scripts based on the funannotate pipeline [31] and antiSMASH (antibiotics and SM Analysis Shell, v5.0) [32,33]. First, the repetitive elements were masked in the assembled genomes (using funannotate), followed by gene prediction using BUSCO2 to train Augustus and self-training GeneMark-ES [34]. Functional annotation was then automatically carried out with InterProScan [35], eggNOG-mapper [36,37] and BUSCO [30] ascomycota_odb10 models. Secreted proteins were predicted using SignalP [38] as implemented in funannotate 'annotate' command. The InterProScan, anti$\mathrm{SMASH}$, and phobius [39] results were automatically generated.

\subsection{Identification of Homologous BGCS}

Homologous clusters between the two P. furfuracea chemotypes were identified by performing reciprocal BLAST searches between the core genes of the BGCs of both genomes. For this, first the core genes from the predicted BGCs of one chemotype were used as 
database and the core genes of the BGCs from the other chemotype as query. The process was then repeated using the other chemotype as database. The homology between the clusters was then confirmed based on sequence similarity and the most similar hit of the core gene in the MIBiG v2 [40] (minimum information about a biosynthetic gene cluster) database (Supplementary Table S2).

Homologous clusters were visualized using synteny plots as implemented in Easyfig v2.2.3 [41]. The GBK input files for Easyfig were generated with seqkit v0.10.1 [42] and the seqret tool from EMBOSS v6.6.0.0 [43]. Easyfig was run with tblastx v2.6.0+, a minimum identity value of 90 , and a minimum length of 50 to draw the blast hits [44]. Clusters were manually matched for orientation so that the core genes were oriented in the same direction. For six BGCs, no corresponding cluster was detected in the other chemotype (Table 2, Supplementary Table S2).

Table 2. Number of raw DNA reads normalized by number of reads and gene length aligned to the core genes of the clusters detected in only one chemotype.

\begin{tabular}{|c|c|c|c|c|c|}
\hline \multicolumn{6}{|c|}{ Clusters Detected in Only One Chemotype } \\
\hline Cluster Number & Name of the Cluster & Detected in & Core Gene & $\begin{array}{l}\text { Normalized Read } \\
\text { Count in Physodic } \\
\text { Acid Chemotype }\end{array}$ & $\begin{array}{l}\text { Normalized Read } \\
\text { Count in Olivetoric } \\
\text { Acid Chemotype }\end{array}$ \\
\hline 52 & Region 7.2 & physodic acid chemotype & R-PKS & 24.66 & 0 \\
\hline 53 & Region 25.1 & physodic acid chemotype & R-PKS & 11.50 & 0 \\
\hline 54 & Region 60.2 & physodic acid chemotype & hybrid & 24.44 & 0 \\
\hline 55 & Region 65.1 & physodic acid chemotype & R-PKS & 18.30 & 0 \\
\hline 56 & Region 27.1 & physodic acid chemotype & terpene & 59.99 & 0 \\
\hline 57 & Region 10.1 & olivetoric acid chemotype & terpene & 0 & 133.94 \\
\hline \multicolumn{6}{|c|}{ Clusters present in both chemotypes } \\
\hline 1 & Region 12.3 & both chemotypes & NR-PKS & 18.19 & 47.66 \\
\hline 2 & Region 18.1 & both chemotypes & NR-PKS & 16.43 & 56.19 \\
\hline 3 & Region 44.1 & both chemotypes & NR-PKS & 29.05 & 43.41 \\
\hline 4 & Region 33.1 & both chemotypes & NR-PKS & 37.08 & 42.14 \\
\hline 9 & Region 10.1 & both chemotypes & R-PKS & 20.14 & 45.88 \\
\hline 11 & Region 16.1 & both chemotypes & R-PKS & 25.53 & 48.84 \\
\hline 12 & Region 2.4 & both chemotypes & R-PKS & 33.33 & 42.85 \\
\hline 15 & Region 9.2 & both chemotypes & R-PKS & 35.00 & 39.86 \\
\hline 6 & Region 9.3 & both chemotypes & R-PKS & 23.87 & 41.47 \\
\hline 5 & Region 2.2 & both chemotypes & R-PKS & 26.24 & 53.15 \\
\hline 44 & Region 38.1 & both chemotypes & terpene & 40.34 & 107.15 \\
\hline 45 & Region 33.2 & both chemotypes & terpene & 83.56 & 119.52 \\
\hline 46 & Region 2.3 & both chemotypes & terpene & 37.49 & 114.33 \\
\hline 47 & Region 12.2 & both chemotypes & terpene & 50.63 & 149.93 \\
\hline 48 & Region 60.1 & both chemotypes & terpene & 51.24 & 85.36 \\
\hline
\end{tabular}

Properties of the clusters detected in only one chemotype including the core gene and its length, number of raw DNA reads and normalized read counts (by number of reads and gene length (RPKM approach)) aligned to the core genes of the clusters detected in only one chemotype.

\subsection{Phylogenetic Analyses}

NR-PKSs have been divided into nine groups based on protein sequence similarity and PKS domain architecture [11,44,45]. We took representative PKSs from each group (amino acid sequences) and added the amino acid sequences of the eight NR-PKSs from P. furfuracea. The dataset includes 107 PKS sequences from Cladonia borealis, C. grayi, C. macilenta, C. metacorallifera, C. rangiferina, C. uncialis, Pseudevernia furfuracea and Stereocaulon alpinum. Sequences were aligned using MAFFT as implemented in Geneious v5.4. Gaps were treated as missing data. The maximum likelihood search was performed on the aligned amino acid sequences with RAxML-HPC BlackBox v8.1.11 [45,46] on the Cipres Scientific gateway [47].

\subsection{Candidate Cluster for Olivetoric Acid and Physodic Acid Biosynthesis}

In addition to the phylogenetic evidence, we implemented several criteria to select the candidate cluster for depside/depsidone synthesis in P. furfuracea: (1) it must be 
present in both chemotypes (presence in both chemotypes is expected as the basic structure of olivetoric acid and physodic acid is the same except that physodic acid contains an additional ether bond (Figure 1)), (2) it must contain an NR-PKS (the non-reduced backbone of lichen depsides/depsidones indicates that the PKSs involved in their synthesis are NR$P K S$ s), and (3) the NR-PKS must contain two ACPs (the presence of two ACPs has been associated with depside production in fungi [12,48], and is a typical feature of lichenforming fungal NR-PKSs involved in depside/depsidone synthesis [10,49]. Additionally, in the physodic acid producer the candidate BGC must contain a CytP450 which produces depsidones by forming the ether bond between the two orsellinic rings of the depside [10].

Summarizing, the following criteria were used for the identification of olivetoric acid and physodic acid BGC: (1) the candidate BGC should be homologous and present in both chemotypes, (2) it must contain an NR-PKS, (3) presence of a CytP450, and (4) presence of two ACP domains in the PKS.

\subsection{Identification of HexA and HexB}

Metabolite FASs consist of a HexA/B multienzyme complex $[13,16]$. Homologous of HexA and HexB were identified by blasting (blastN) the HexA and $\underline{\operatorname{HexB}}$ homologs of Cladonia grayi (CLAGR_008938-RA and CLAGR_008939-RA, available at https:/ / mycocosm.jgi.doe. gov /Clagr3/Clagr3.info.html, 25 September 2011) against the genomes of both chemotypes.

\subsection{Metatranscriptome Analyses and Quantification of PKS, CytP450 and HexA and HexB Transcripts}

The details of RNA isolation and transcriptome extraction are given in Meiser et al. [7]. Briefly, for RNA isolation, whole lichen thalli were collected and stored directly in RNAlater (Sigma-Aldrich Chemie GmbH, Munich, Germany). RNA was isolated from both chemotypes of P. furfuracea by using the method described by Rubio-Piña and Zapata-Pérez [50] after blotting the thalli dry and grinding them in liquid nitrogen with a mortar and pestle. The isolated poly-A+ RNA was further purified with the RNeasy MinElute Clean-up Kit (Qiagen, Hilden, Germany), and sequenced (250 bp paired-end reads) on Illumina MiSeq at StarSeq (Mainz, Germany).

The BGC for depside/depsidone biosynthesis in each chemotype contains 10 genes including one Pfur33-1_006185, one CytP450, and a monooxygenase (see below). The other seven code for unidentified proteins. We used transcriptome data to check which genes in this cluster are transcriptionally active. For this, we first indexed the sequence of interest using bowtie v2 [51] and then aligned it to the transcripts (both paired and unpaired reads) using TopHat v2 [52]. To make the counts comparable between chemotypes we used RPKM normalization of the read counts [53], accounting for sequencing depth and gene length [54-56]. The normalization for sequencing depth was performed by dividing the raw read count of the given gene by the total number of reads in each sample. The resulting number was then divided by gene length (in kilobases) to obtain RPKM normalized counts.

\section{Results}

\subsection{Genomes of the P. furfuracea Chemotypes}

The number of reads for each sample retained after quality and length filtering is given in Table 1. The reference genome of the PacBio-based P. furfuracea physodic acid chemotype (NCBI acc. no. JAIUPS000000000) is $~ 34 \mathrm{Mb}$ in length and has a completeness of $96 \%$ according to BUSCO (details in Table 1). The genome of the olivetoric acid chemotype (NCBI acc. no. JAIUPT000000000) is $~ 37 \mathrm{Mb}$ in length and has a completeness of $92 \%$ according to BUSCO (details in Table 1). The data related to this project is submitted to NCBI under the BioProject number PRJNA764874.

\subsection{Predicted BGCs}

A total of 51 homologous BGCs were present in both chemotypes: 14 clusters with reducing $P K S s(R-P K S)$, eight clusters with $N R-P K S s$, one cluster with type III $P K S$, seven 
hybrid clusters, 14 clusters with NRPS or NRPS-like genes, five clusters with a terpene synthase, and two clusters with an indole synthase as a core gene (Supplementary Table S2). Six BGCs were found only in one of the two chemotypes (Table 2). Five BGCs were only present in the physodic acid chemotype (four BGCs with a $R-P K S$, a hybrid cluster with a $R-P K S$ and an NRPS, and a cluster with a terpene synthase as the core gene), and one BGC with a terpene synthase as the core gene was present only in the olivetoric acid chemotype (Table 2).

\subsection{Phylogenetic Analyses}

Out of eight NR-PKSs, only two, Pfur33-1_006185 and Pfur2-2_003072, grouped into phylogenetic group I, whose PKSs are involved in the synthesis of orcinol derivatives (Figure 2), such as grayanic acid, olivetoric acid and physodic acid (phylogeny was based on amino acid sequences). Of these PKSs, Pfur33-1_006185, was closely related to PKS16, the PKS associated with grayanic acid biosynthesis from Cladonia grayi, whereas Pfur22_003072 was closely related to PKS27. PKS16 and PKS27 refer to the PKS numbering used in Kim et al. [11]. The Pfur33-1_006185 cluster also contains a CytP450 next to the NR-PKS in an arrangement analogous to that in the PKS16 cluster in C. grayi.

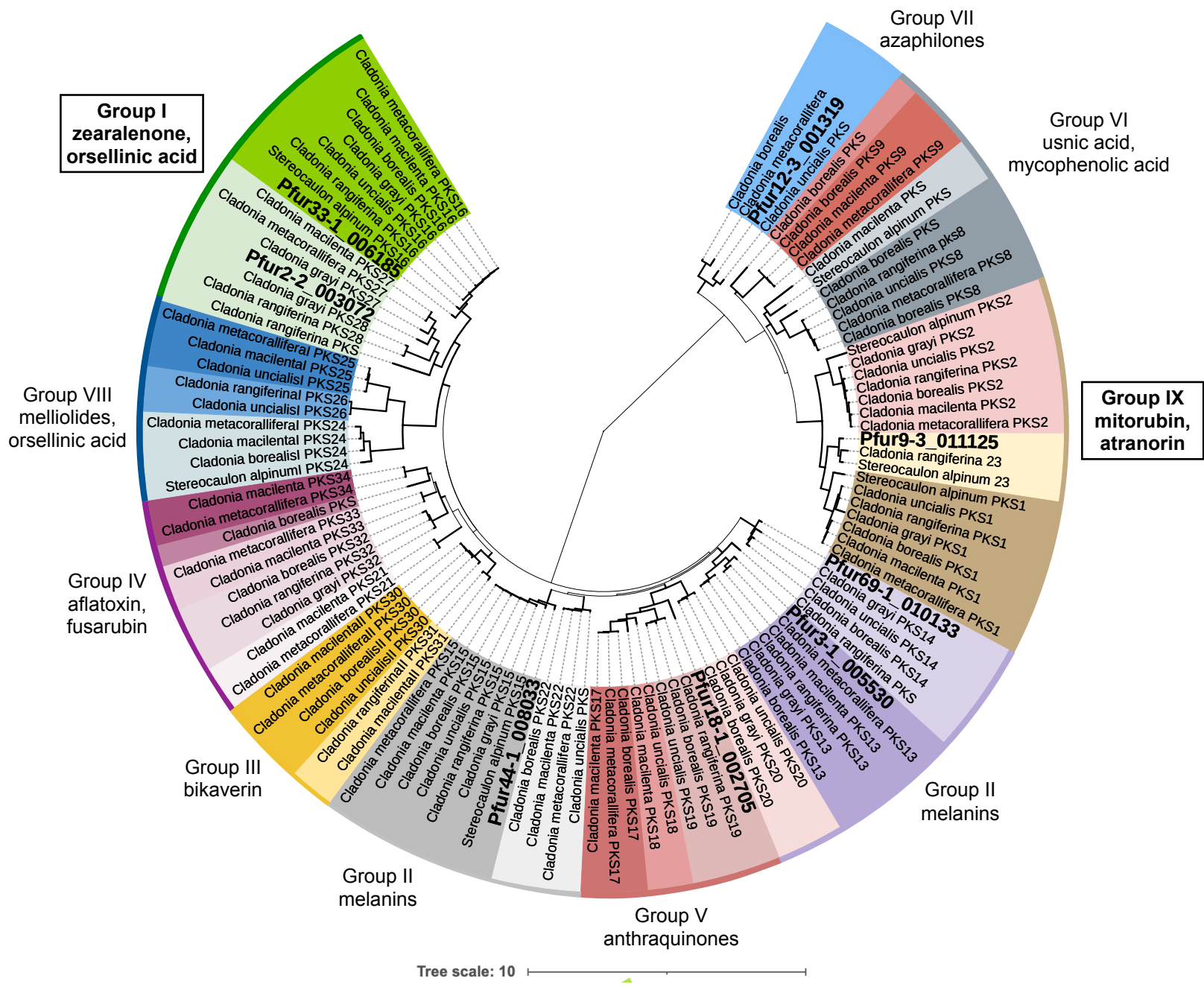

Figure 2. Phylogeny of NR-PKSs of lichen-forming fungi. This is a maximum likelihood tree based on 107 NR-PKSs amino acid sequences from six Cladonia spp., Stereocaulon alpinum and P. furfuracea. Branches in bold indicate bootstrap support $>70 \%$. Different colors indicate different PKS groups based on Kim et al. [11]. PKSs of P. furfuracea are indicated in bold and with larger fonts. 


\subsection{Selection of the Candidate Cluster for Olivetoric Acid and Physodic Acid}

We complemented the phylogenetic evidence with the other characteristics of the cluster to select the possible olivetoric acid and physodic acid cluster. We found eight clusters containing an NR-PKS that were present in both chemotypes (Supplementary Tables S2 and S3). Of these, only one cluster, cluster 4 (Table 3), contained an NR-PKS with two ACP domains and a CytP450 in the cluster. The domains of this PKS are - SAT-KS-ATACP-ACP-TE (Figure 3). The most similar PKS to this is the PKS linked to grayanic acid biosynthesis, PKS16. We therefore propose cluster 4 to be the most likely candidate for the synthesis of olivetoric acid and physodic acid in P. furfuracea. The cluster has an almost identical structure in both chemotypes, with 10 genes including an NR-PKS, a CytP450, and a monooxygenase (Figure 3). The protein products of the remaining seven genes are unidentified.

Table 3. NR-PKS clusters detected in both chemotypes of $P$. furfuracea, the PKS domains and other genes present in the cluster.

\begin{tabular}{|c|c|c|c|c|c|c|c|c|}
\hline $\begin{array}{l}\text { Cluster } \\
\text { Number }\end{array}$ & PKS & $\begin{array}{l}\text { Compound } \\
\text { Defining the } \\
\text { Group } \\
\text { (Kim et al. [11]) }\end{array}$ & $\begin{array}{l}\text { PKS Category } \\
\text { (Kim et al. [11]) }\end{array}$ & PKS Domains & $\begin{array}{c}\text { Total Genes } \\
\text { in the } \\
\text { Cluster }\end{array}$ & $\begin{array}{l}\text { Identified Genes in } \\
\text { Cluster }\end{array}$ & $\begin{array}{l}\text { Most Similar } \\
\text { Known PKS } \\
\text { (MIBiG) }\end{array}$ & $\begin{array}{c}\text { Coverage and } \\
\text { Similarity to } \\
\text { MIBiG } \\
\text { Cluster }\end{array}$ \\
\hline 1 & $\begin{array}{l}\text { Pfur12- } \\
\text { 3_001319 }\end{array}$ & $\begin{array}{l}\text { VII (azaphilones, } \\
\text { monascorubrin) }\end{array}$ & not known & $\begin{array}{l}\text { SAT-KS-AT- } \\
\text { ACP } \\
\text { cMT-TD }\end{array}$ & 12 & $\begin{array}{c}\text { Regulatory gene, } \\
\text { NRPKS }\end{array}$ & monascorubrin & $95 \%, 58 \%$ \\
\hline 2 & $\begin{array}{l}\text { Pfur18- } \\
\text { 1_002705 }\end{array}$ & $\begin{array}{c}\mathrm{V} \\
\text { (anthraquinones) }\end{array}$ & PKS20 & $\begin{array}{l}\text { SAT-KS-AT- } \\
\text { PT-ACP }\end{array}$ & 16 & $\begin{array}{l}\text { metallo-beta-lactamase } \\
\text { family protein, } \\
\text { NRPKS, halogenase }\end{array}$ & RES-1214-2 & $61 \%, 100 \%$ \\
\hline 3 & $\begin{array}{l}\text { Pfur44- } \\
1 \_008033\end{array}$ & II (melanins) & PKS15 & $\begin{array}{l}\text { SAT-KS-AT- } \\
\text { PT-ACP } \\
\text { ACP-TE }\end{array}$ & 11 & $\begin{array}{c}\text { PKS, dehydroge- } \\
\text { nase/reductase } \\
(\mathrm{KR})\end{array}$ & naphthalene & $99.5 \%, 53 \%$ \\
\hline 4 & $\begin{array}{l}\text { Pfur33- } \\
\text { 1_006185 }\end{array}$ & $\begin{array}{l}\text { I (zearalenone, } \\
\text { orsellinic acid) }\end{array}$ & PKS16 & $\begin{array}{c}\text { SAT-KS-AT- } \\
\text { ACP } \\
\text { ACP-TE }\end{array}$ & 10 & $\begin{array}{c}\text { CytP450, PKS, } \\
\text { monooxygenase }\end{array}$ & grayanic acid & $99 \%, 73 \%$ \\
\hline 5 & $\begin{array}{l}\text { Pfur2- } \\
\text { 2_003072 }\end{array}$ & $\begin{array}{l}\text { I (zearalenone, } \\
\text { orsellinic acid) }\end{array}$ & PKS27 & $\begin{array}{l}\text { SAT-KS-AT- } \\
\text { PT-ACP-TE }\end{array}$ & 13 & $\begin{array}{c}\text { O-methyltransferase, } \\
\text { CytP450, crotonyl-CoA } \\
\text { reductase/alcohol } \\
\text { dehydrogenase, } \\
\text { red-PKS, NRPKS, } \\
\text { GATase_7 }\end{array}$ & grayanic acid & $100 \%, 38 \%$ \\
\hline 6 & $\begin{array}{l}\text { Pfur9- } \\
\text { 3_011125 }\end{array}$ & $\begin{array}{l}\text { IX (mitorubin, } \\
\text { atranorin) }\end{array}$ & PKS23 & $\begin{array}{l}\text { SAT-KS-AT- } \\
\text { PT-ACP } \\
\text { cMT }\end{array}$ & 11 & $\begin{array}{l}\text { alkyl hydroperoxide } \\
\text { reductase/Thiol } \\
\text { specific, PKS, CytP450, } \\
\text { drug resistance } \\
\text { transporter }\end{array}$ & $\begin{array}{l}\text { ascochlorin } \\
\text { cluster } \\
\text { (Acremonium } \\
\text { egyptiacum) }\end{array}$ & $100 \%, 38 \%$ \\
\hline 7 & $\begin{array}{l}\text { Pfur3- } \\
\text { 1_005530 }\end{array}$ & II (melanins) & PKS13 & $\begin{array}{l}\text { SAT-KS-AT- } \\
\text { PT-ACP-ACP- } \\
\text { TE }\end{array}$ & 13 & $\begin{array}{l}\text { serine/threonine } \\
\text { protein kinase, Drug } \\
\text { resistance transporter, } \\
\text { monooxygenase } \\
\text { FAD-binding, NRPKS, } \\
\text { short-chain dehydroge- } \\
\text { nase/reductase SDR, } \\
\text { O-methyltransferase, } \\
\text { transcription regulator }\end{array}$ & & $100 \%, 48 \%$ \\
\hline 8 & $\begin{array}{l}\text { Pfur69- } \\
\text { 1_010133 }\end{array}$ & II (melanins) & PKS14 & $\begin{array}{l}\text { SAT-KS-AT- } \\
\text { PT-ACP-ACP- } \\
\text { TE }\end{array}$ & 9 & $\begin{array}{c}\text { Drug resistance } \\
\text { transporter, } \\
\text { O-methyltransferase, } \\
\text { halogenase, } \\
\text { monooxygenase } \\
\text { FAD-binding, } \\
\text { adh_short (DH-KR), } \\
\text { NRPKS, } \\
\text { monooxygenase } \\
\text { FAD-binding }\end{array}$ & $\begin{array}{c}\text { 6- } \\
\text { hydroxymellein } \\
\text { (Cladonia } \\
\text { uncialis) }\end{array}$ & $99 \%, 78 \%$ \\
\hline
\end{tabular}

Properties of the NR-PKS clusters detected in both the chemotypes of $P$. furfuracea. NR-PKS = non-reducing PKS. The cluster in bold, in the box (cluster 4 containing Pfur33-1_006185), is the likely cluster for depside/depsidone synthesis. The domain acronyms stand for: KS = keto-synthase, $\mathrm{AT}=$ acyltransferase, $\mathrm{ACP}=$ acyl carrier protein and $\mathrm{KR}=$ ketoreductase. The PKS category is based on the phylogenetic placements of the P. furfuracea NR-PKSs in the PKS groups from Kim et al. [11]. Cluster number refers to Supplementary Table S2 and the PKS number to the antiSMASH cluster, followed by the gene number. 


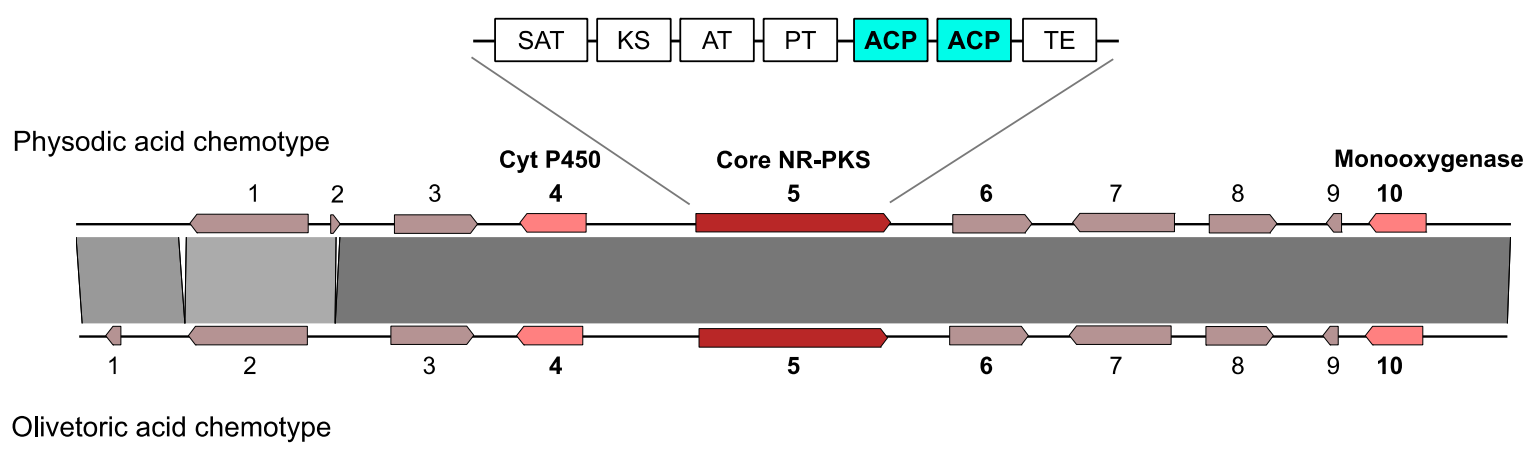

Figure 3. Synteny plot based on tBLASTn depicting conservation and synteny between the homologous putative cluster for the synthesis of the depsidone physodic acid and the depside olivetoric acid in P. furfuracea. Bolded numbers represent the genes that are predominantly expressed. Domains of the PKS are schematized on top.

We excluded the other seven NR-PKS clusters as possible candidates for the biosynthesis of olivetoric acid and physodic acid based on the following reasons: Cluster 1 has a cMT domain in the PKS, lacks CytP450 and its PKS groups with group VII PKSs associated with the synthesis of azaphilones, monascorubrin, and related compounds. The PKS of cluster 2 lacks a TE domain and groups with PKSs linked to anthraquinone biosynthesis (group VII). Cytochrome P450 is not present in this cluster. In cluster 3 CytP450 is absent and the PKS groups with PKSs associated with melanin synthesis (group V). Cluster 5 contains a $R-P K S$ and an NR-PKS next to each other divergently transcribed from the same region, suggesting common regulation and no connection to olivetoric acid synthesis. This cluster does contain a CytP450, but also an O-methyltransferase (OMT) which is not required for olivetoric acid or physodic acid synthesis. Cluster 6 contains a CytP450, but the PKS has a cMT domain and groups phylogenetically with atranorin-synthesizing PKSs (group IX). This is the most likely cluster involved in the synthesis of atranorin (see next paragraph). Clusters 7 and 8 lack CytP450, contain an OMT, and the PKSs group with melanin-synthesizing PKSs (group II).

\subsection{A Putative Atranorin Cluster Is Present in P. furfuracea}

Apart from the orcinol-derived olivetoric acid and physodic acid, atranorin (a Borcinol depside) is a common secondary metabolite produced by both chemotypes of $P$. furfuracea. Recently, the atranorin cluster from Cladonia rangiferina was characterized and heterologously expressed [11]. Its PKS, PKS23, belongs to group IX (Figure 2). An atranorin PKS is expected to have the following domains: SAT-KS-AT-PT-ACP-cMT-TE. In our study, PKS Pfur9-3_011125 has this domain architecture and groups phylogenetically with the atranorin cluster of Cladonia rangiferina. This cluster is present in both chemotypes and has a gene composition similar to the atr 1 cluster of $C$. rangiferina, i.e., it has a CytP450, an OMT, and a transporter gene. We propose that this cluster is the atranorin cluster of $P$. furfuracea.

\subsection{The Two Genes for a Metabolite FAS Are Present in P. furfuracea}

Aspergillus nidulans has a metabolite FAS with properties similar to those expected for the unexplored lichen metabolite FASs. The A. nidulans FAS enzyme comprises two subunits, HexA and HexB, which produce and deliver to the aflatoxin NR-PKS the hexanoyl starter for norsolorinic acid, the first metabolite in the aflatoxin pathway $[15,16]$. We used the Cladonia grayi homologs of HexA and HexB (Dal Grande et al., in preparation) to search for the corresponding genes in P. furfuracea. We found one 5619-bp HexA homolog and one 6285-bp HexB homolog. As in A. nidulans and C. grayi, in both chemotypes of P. furfuracea these genes are adjacent and divergently transcribed from the same control region (genes FUN_005930 and FUN_005931 in the olivetoric acid chemotype; genes FUN_004275 and FUN_004276 in the physodic acid chemotype). These FAS subunit genes are not linked to the olivetoric acid or physodic acid cluster. 


\subsection{Transcription of the Olivetoric Acid and Physodic Acid Cluster and of HexA and HexB}

We checked the transcription of the genes of interest (genes of cluster 4 and HexA and $H e x B$ ) in lichen thalli of both chemotypes. In general, average transcription across the genome was lower in the olivetoric acid than in the physodic acid chemotype. This was reflected in the clusters as well. Transcriptome data suggest that in cluster 4 , three genes out of 10, namely Pfur33-1_006185, the CytP450, and gene6 (coding for an unknown protein) were transcriptionally active. We inferred the relative transcription activity by comparing the number of transcriptome raw reads (normalized by counts per million and length) that aligned to the respective gene (Table 4). Relative to the physodic acid (depsidone) chemotype, in the olivetoric acid (depside) chemotype all genes of cluster4 showed low transcription activity, although as compared to the other genes in the cluster the same three genes, NR-PKS, CytP450, and gene6 showed higher transcription activity. HexA and HexB were transcribed in both chemotypes. The number of read counts, however, was higher in the physodic acid chemotype than in the olivetoric acid chemotype. This parallels the behavior of the cluster 4 genes (Table 4 ).

Table 4. Read count of the genes of cluster 4 and P. furfuracea homologs of HexA and HexB of the physodic acid and olivetoric acid chemotype.

\begin{tabular}{|c|c|c|c|c|c|c|}
\hline \multirow[b]{2}{*}{ Gene } & \multirow[b]{2}{*}{ Gene Identity } & \multirow[b]{2}{*}{ Gene Length } & \multicolumn{2}{|c|}{ Physodic Acid Chemotype } & \multicolumn{2}{|c|}{ Olivetoric Acid Chemotype } \\
\hline & & & $\begin{array}{c}\text { Number of } \\
\text { Raw Reads } \\
\text { Aligned }\end{array}$ & $\begin{array}{c}\text { Reads } \\
\text { (Normalized } \\
\text { by CPM) }\end{array}$ & $\begin{array}{c}\text { \# Raw Reads } \\
\text { Aligned }\end{array}$ & $\begin{array}{c}\text { Reads } \\
\text { (Normalized } \\
\text { by CPM) }\end{array}$ \\
\hline cluster 4 gene1 & unidentified & 3822 & 38 & 0 & no hits & - \\
\hline cluster 4 gene2 & unidentified & 306 & no hits & - & 1 & 0 \\
\hline cluster 4 gene 3 & unidentified & 2685 & no hits & - & 19 & 0 \\
\hline cluster 4 gene 4 & CytP450 & 2139 & 8677 & 117.29 & 1222 & 17.4 \\
\hline cluster 4 gene 5 & NR-PKS & 6294 & 111226 & 511 & 1265 & 6.33 \\
\hline cluster 4 gene6 & unidentified & 2550 & 13690 & 155.25 & 6304 & 75.38 \\
\hline cluster 4 gene7 & unidentified & 3284 & 1035 & 9.11 & 118 & 1.125 \\
\hline cluster 4 gene8 & unidentified & 2191 & 936 & 12.35 & 205 & 1.98 \\
\hline cluster 4 gene 9 & unidentified & 492 & no hits & - & 12 & 0.73 \\
\hline cluster 4 gene10 & monooxygenase & 1851 & 46 & 0.71 & 19 & 0.307 \\
\hline FAS & FAS-A & 5619 & 3143 & 16.17 & 944 & 5.12 \\
\hline FAS & FAS-B & 6285 & 1971 & 9.06 & 911 & 4.42 \\
\hline
\end{tabular}

Read count of the genes of cluster 4 and P. furfuracea homologs of $H e x A$ and $H e x B$ of the physodic acid and olivetoric acid chemotype. Transcriptome raw reads and normalized read counts (by number of reads and gene length (RPKM approach)) aligned to the ten genes of the candidate physodic acid and olivetoric acid cluster. Genes in bold (gene 4, 5, and 6) have the highest read counts.

\section{Discussion}

In this study we describe the putative BGCs for the biosynthesis of olivetoric acid and physodic acid in the lichen-forming fungus $P$. furfuracea from high-quality long-read genome assemblies of the two chemotypes. Furthermore, we identify the HexA and HexB homologs in P. furfuracea, likely to deliver the starters to the orcinol compound PKSs. Combining our findings with those of Kealey et al. [18] and of other literature data, we propose an outline for the origin of the starter unit, chemotype variation, and synthesis of orcinol depsides and depsidones in lichens.

\subsection{True Intraspecific Variation Underlies Differences in BGCs between Chemotypes}

While most BGCs (51) were present in both chemotypes, six BGCs were present only in one chemotype (Supplementary Information Table S2). In principle, the differences might be attributed to (i) random variation in sequencing depth, (ii) contamination by another fungus, and (iii) true intraspecific variation. Random sequencing depth variation can be excluded because we detected no reads of the missing BGC in the raw data. It is very unlikely that large genomic regions, such as entire BGCs, would be missed due to uneven coverage. Contamination from reads of minority fungal genomes (e.g., from 
lichenicolous fungi) can also be excluded, as we did not detect any coverage variation with underrepresented sequences compared to those from the main mycobiont. Furthermore, the clusters detected only in the physodic acid chemotype were also absent in the previously sequenced genome of $P$. furfuracea of the olivetoric acid chemotype [7]. True intraspecific variation is therefore the most likely cause of the observed differences in BGC content between chemotypes.

Intraspecies variations in BGCs have been reported for plants, bacteria, and fungi, and have been linked to ecological adaptation [57-60]. For instance, the number of BGCs may vary between populations inhabiting different climatic conditions [57,61]. In fact, fungal BGCs are suggested to be hotspots of gene gain/loss and duplication [62-64]. Different strains of a single species can contain up to 15 strain-specific clusters [65]. The presence of unique BGCs suggests that each chemotype has a specialized metabolite potential based on genetic differences. Genome sequences of only two individuals are not likely to capture the pangenomic variation of BGCs within P. furfuracea. BGC variation among individuals of a species appears to be a common phenomenon and therefore a single individual may not represent the entire biosynthetic potential of a species [62,66,67]. However, intraspecific biosynthetic variation can also arise when the BGCs involved are present in all individuals, as exemplified by the BGC likely responsible for the synthesis of olivetoric acid and physodic acid (see below).

Our results suggest that differences in presence/absence of BGCs are not linked to differences between chemotypes. Although there are many cluster differences between chemotypes, these differences do not affect the chemistry defining the two chemotypes. Instead, the chemotypic differences appear to be due to the divergent regulation of the same cluster present in both chemotypes.

\subsection{The Same Candidate BGC Is Linked to Depside and Depsidone Biosynthesis}

The cluster we identified as the likely BGC linked to the biosynthesis of olivetoric acid and physodic acid has identical gene content in both chemotypes (Figure 3), prompting the question of how one chemotype produces largely the depside olivetoric acid and the other largely the depsidone physodic acid. This cluster includes an NR-PKS and a CytP450 in both chemotypes, although the CytP450 is required only for the depsidone synthesis [10,18]. These are also two of the three most highly transcribed genes in the cluster (Table 4). The function of the other genes, which are unidentified and mostly transcriptionally silent, with regard to olivetoric acid and physodic acid biosynthesis is unknown (Table 4). Theoretically, differential transcription of CytP450 could explain the difference between chemotypes: while the PKS should be expressed in both chemotypes, repression of the CytP450 in the olivetoric acid chemotype would prevent the depside to depsidone transition, whereas expression of the CytP450 in the physodic acid chemotype would allow depsidone synthesis. However, the transcriptome data (Table 4) shows that CytP450 is transcribed in both chemotypes, probably because averaging reads from thalli comprising different developmental and physiological stages cannot reflect subtle developmental transitions occurring at different times and locations. In fact, each chemotype may occasionally produce both, depside and depsidone, probably due to regulatory anomalies, but one of the two compounds may remain below the level of detection. There are reports of occasional thalli of P. furfuracea containing both, physodic acid and olivetoric acid [20].

While at a cellular scale differential transcription is decisive in determining phenotypes in fungi, secondary metabolite synthesis is a complex, multi-step process involving various genetic, epigenetic, and environmental factors that together determine the spatiotemporal secondary metabolite profile of an organism [66-68]. Often, the same BGC can be differentially regulated at the intraspecies level epigentically, posttranscriptionally, or posttranslationally, to produce different compounds [57,69-71]. For instance, the aspyridone cluster in Aspergillus nidulans can produce up to eight different compounds depending on the combination of genes activated [72]. Although our findings cannot explain which aspects of this complexity differentiate the chemotypes of $P$. furfuracea, they clearly indicate 
that differential regulation of the same BGC is involved. Our study shows that the biosynthetic capabilities of organisms may vary within a species and highlights the importance of exploring the biosynthetic potential of organisms at the intraspecies level.

\subsection{A Metabolite Fatty Acid Synthase Is the Likely Provider of the Hexanoyl Starter for Olivetoric} Acid Synthesis

We found the homologs of HexA and HexB in P. furfuracea. As in Aspergillus nidulans and Cladonia grayi these genes are located next to each other and in divergent orientation, suggesting that they are co-regulated by the same promoter. HexA and HexB refer respectively to the $\alpha$ and $\beta$ subunits of the hexanoate synthase in $A$. nidulans. The FAS domains ACP, KR, and KS are present in the $\alpha$-chain and AT, ER, DH, and malonyl-ACP transferase (MPT) in the $\beta$-chain [73]. HexA/B provides the hexanoyl starter to the PKS synthesizing the norsolorinic acid precursor of aflatoxin in Aspergillus nidulans. We propose that the HexA/B homolog in P. furfuracea delivers hexanoyl starters to initiate both rings of olivetoric acid, although the A-ring side chain ends up being two carbons longer than the B-ring chain (Figure 4), as described in the next section.

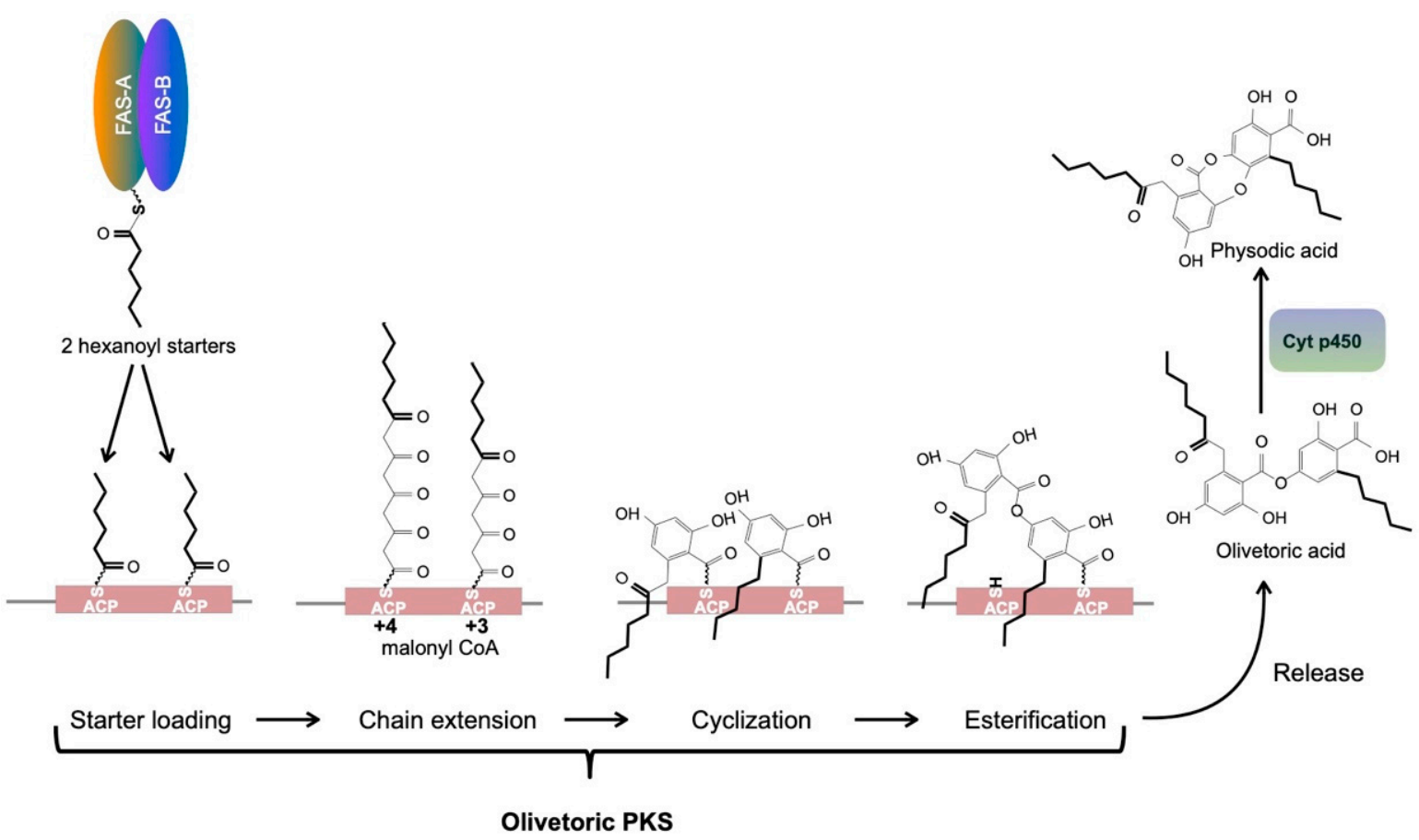

Figure 4. Putative scheme for depside/depsidone synthesis and function of FASs.

The PKS of cluster4 we identified in this study as most likely $P K S$ associated with the biosynthesis of olivetoric acid and physodic acid, is the same as Pfur33-1_006185 that was heterologously expressed in yeast by Kealey et al. [18]. Interestingly, expression of this PKS in the heterologous host yielded lecanoric acid [18], a compound never reported from thalli of $P$. furfuracea. Lecanoric acid and olivetoric acid differ in their starter side chains: both rings of olivetoric acid are started by a hexanoyl chain (Figure 4) whereas both rings in lecanoric acid are started by the two-carbon chain from acetyl-CoA. This indicates that a PKS specific for olivetoric acid in P. furfuracea accepts acetyl-CoA as starter in yeast while it never does so in the lichen where it only accepts hexanoyl chains. Moreover, the heterologously expressed PKS continued to prefer acetyl-CoA in yeast and produced lecanoric acid even when hexanoyl-CoA was provided [18]. A likely solution to these apparent contradictions is that the "default" setting for the olivetoric PKS and perhaps for other orcinol depside PKSs is to accept free acetyl-CoA as starter, but not free acyl-CoAs with longer chains. This default setting is revealed only in the absence of a dedicated metabolite FAS such as the one we identified in the lichen. Yeast has no metabolite FAS 
genes. The task of the metabolite FAS is to transfer directly to the PKS, through specific binding of the two proteins, the hexanoyl chain from the FAS ACP to the PKS ACP, with no free acyl-CoA intermediate. That would explain why in yeast the olivetoric PKS would not use free hexanoyl-CoA. Such an acyl-transfer mechanism is identical to what has been proposed for hexanoyl transfer between the HexA-HexB FAS in A. nidulans and the norsolorinic acid PKS $[15,74]$. Our identification in P. furfuracea of an expressed (Table 4) close homolog of the A. nidulans HexA-HexB FAS provides strong support for our proposed scenario. An important corollary of this scenario is that the side chain specificity in lichen orcinol compounds is not controlled exclusively by PKSs but likely results from specific protein-protein interactions between each PKS and a dedicated metabolite FAS which synthesizes and delivers the appropriate acyl-ACP starter directly to the PKS.

\subsection{An Updated Scheme of Orcinol Depside and Depsidone Synthesis}

We combine here our results with those of Watanabe and Townsend [75], Armaleo et al. [10], Feng et al. [12], Lünne et al. [48], and Kealey et al. [18], to provide an updated scheme of orcinol depside and depsidone synthesis, using as example the synthesis of olivetoric acid and physodic acid. We limit our description to orcinol lichen compounds as we do not yet know how many of the same rules apply to ß-orcinol depsides and depsidones. Orcinol and ß-orcinol PKSs are separated by a deep evolutionary gulf (Figure 2) and the biological differences between these two groups of lichen compounds are not well understood.

The scheme is depicted in Figure 4. Unless acetyl-CoA provides the starter, as is the case for lecanoric acid and other orcinol compounds with methyl groups as side chains, a dedicated HexA/B FAS is needed to provide an acyl-ACP as starter to the PKS. In the case of olivetoric acid, hexanoyl-ACP is the starter for both rings and is transferred within the two proteins bound to each other from the FAS-ACP to the PKS-ACPs (Figure 4). The symmetric addition of starters is not the rule, as many orcinol compounds use different acyl chain starters for the two rings. Polyketide extension involves a minimum of three malonyl-CoA additions but can involve four. The PKS then cyclizes both polyketide chains to orcinol rings, esterifies the carboxyl of the $\mathrm{A}$ ring with the $4^{\prime} \mathrm{OH}$ of the $\mathrm{B}$ ring and finally releases the depside by hydrolysis of the $\mathrm{B}$ ring thioester. The rings produced after four malonyl additions commonly have side chains with a ß-keto group derived from the carbonyl oxygen of the hexanoyl starter (Figure 4), as seen on the A ring side chain of olivetoric acid and physodic acid. If the released depside is to be turned into a depsidone, a dedicated cytochrome $\mathrm{P} 450$ adds an ether bond, oxidatively coupling the $\mathrm{C} 2 \mathrm{OH}$ of the $\mathrm{A}$ ring to the $5^{\prime} \mathrm{C}$ of the $\mathrm{B}$ ring.

\section{Conclusions}

Our study contributes to the understanding of natural product synthesis in lichenized fungi in several ways. We identified the BGCs of the two P. furfuracea chemotypes and highlighted the putative cluster linked to the biosynthesis of olivetoric acid and physodic acid. Additionally, we identified the P. furfuracea homologs of HexA / B, the first FAS from lichen-forming fungi putatively involved in metabolite synthesis. Taken together, our results show that the same BGC has the potential to produce different compounds and suggests that intraspecific variation in the regulation of metabolite synthesis adds to the biosynthetic diversity and potential of organisms despite similar BGC content. Our study helps clarify some of the components determining chemotype variability in lichens and, in combination with other data, has allowed us to devise the most detailed scheme to date for the synthesis of orcinol depsides and depsidones. However, although the scheme combines the available evidence in a way consistent with the known molecular biology and biochemistry of these compounds, a number of details remain hypothetical and need experimental confirmation. These include the specificity and order of starter addition for each ACP on the PKS, the interdependence of the elongation of two malonyl chains on one PKS, and the CytP450 oxidation of a depside to a depsidone. 
Supplementary Materials: The following are available online at https: / www.mdpi.com/article/ 10.3390/biom11101445/s1, Table S1: Voucher information of the samples used for the study, Table S2: Details of the estimated biosynthetic gene clusters in the two chemotypes of $P$. furfuracea. PKS number (column 2) refers to the most closely related PKS in the maximum likelihood tree presented in Figure 2. Region (column 3) refers to the cluster number and regions in the antiSMASH output.

Author Contributions: Conceptualization, G.S., D.A. and I.S.; methodology, G.S., F.D.G., D.A. and I.S.; validation, G.S., F.D.G., D.A. and I.S.; formal analysis, G.S. and D.A.; resources, I.S.; data curation, G.S.; writing—original draft preparation, G.S. and D.A.; writing-review and editing, G.S., D.A., F.D.G. and I.S.; visualization, G.S. and D.A.; supervision, D.A. and I.S.; funding acquisition, I.S. All authors have read and agreed to the published version of the manuscript.

Funding: This research was funded by LOEWE-Centre TBG funded by the Hessen State Ministry of Higher Education, Research and the Arts (HMWK).

Institutional Review Board Statement: Not applicable.

Informed Consent Statement: Not applicable.

Data Availability Statement: The data used for the study is deposited in NCBI under the BioProject number PRJNA764874. The raw data is available from SRA under the same BioProject.

Acknowledgments: We thank Jürgen Otte (Frankfurt) for help in the lab, and Anjuli Calchera (Frankfurt) for HPLC analysis and technical support.

Conflicts of Interest: The authors declare no conflict of interest.

\section{References}

1. Shukla, V.; Joshi, G.P.; Rawat, M.S.M. Lichens as a potential natural source of bioactive compounds: A review. Phytochem. Rev. 2010, 9, 303-314. [CrossRef]

2. Shrestha, G.; St. Clair, L.L. Lichens: A promising source of antibiotic and anticancer drugs. Phytochem. Rev. 2013, 12, 229-244. [CrossRef]

3. Ingelfinger, R.; Henke, M.; Roser, L.; Ulshöfer, T.; Calchera, A.; Singh, G.; Parnham, M.J.; Geisslinger, G.; Fürst, R.; Schmitt, I.; et al. Unraveling the pharmacological potential of lichen extracts in the context of cancer and inflammation with a broad screening approach. Front. Pharmacol. 2020, 11, 1322. [CrossRef] [PubMed]

4. Seshadri, T.R. A theory of biogenesis of lichen depsides and depsidones. Proc. Indian Acad. Sci. 1944, 20A, 1-14. [CrossRef]

5. Elix, J.; Jenie, U.; Parker, J. A novel synthesis of the lichen depsidones divaronic acid and stenosporonic acid, and the biosynthetic implications. Aust. J. Chem. 1987, 40,1451-1464. [CrossRef]

6. Calchera, A.; Dal Grande, F.; Bode, H.B.; Schmitt, I. Biosynthetic gene content of the "perfume lichens" Evernia prunastri and Pseudevernia furfuracea. Molecules 2019, 24, 203. [CrossRef]

7. Meiser, A.; Otte, J.; Schmitt, I.; Grande, F.D. Sequencing genomes from mixed DNA samples - Evaluating the metagenome skimming approach in lichenized fungi. Sci. Rep. 2017, 7, 1-13. [CrossRef]

8. Kroken, S.; Glass, N.L.; Taylor, J.W.; Yoder, O.C.; Turgeon, B.G. Phylogenomic analysis of type I polyketide synthase genes in pathogenic and saprobic ascomycetes. Proc. Natl. Acad. Sci. USA 2003, 100, 15670-15675. [CrossRef]

9. Cox, R.J.; Simpson, T.J. Fungal type I polyketide synthases. Methods Enzymol. 2009, 459, 49-78.

10. Armaleo, D.; Sun, X.; Culberson, C. Insights from the first putative biosynthetic gene cluster for a lichen depside and depsidone. Mycologia 2011, 103, 741-754. [CrossRef]

11. Kim, W.; Liu, R.; Woo, S.; Kang, K.B.; Park, H.; Yu, Y.H.; Ha, H.-H.; Oh, S.-Y.; Yang, J.H.; Kim, H.; et al. Linking a gene cluster to atranorin, a major cortical substance of lichens, through genetic dereplication and heterologous expression. MBio 2021 , e0111121.

12. Feng, C.; Wei, Q.; Hu, C.; Zou, Y. Biosynthesis of diphenyl ethers in fungi. Org. Lett. 2019, 21, 3114-3118. [CrossRef]

13. Hitchman, T.S.; Schmidt, E.W.; Trail, F.; Rarick, M.D.; Linz, J.E.; Townsend, C.A. Hexanoate synthase, a specialized type I fatty acid synthase in aflatoxin B1 biosynthesis. Bioorg. Chem. 2001, 29, 293-307. [CrossRef]

14. Smith, S.; Tsai, S.C. The type I fatty acid and polyketide synthases: A tale of two megasynthases. Nat. Prod. Rep. 2007, 24, 1041-1072. [CrossRef]

15. Watanabe, C.M.H.; Townsend, C.A. Initial characterization of a type I fatty acid synthase and polyketide synthase multienzyme complex NorS in the biosynthesis of aflatoxin B1. Chem. Biol. 2002, 9, 981-988. [CrossRef]

16. Brown, D.W.; Adams, T.H.; Keller, N.P. Aspergillus has distinct fatty acid synthases for primary and secondary metabolism. Proc. Natl. Acad. Sci. USA 1996, 93, 14873-14877. [CrossRef] [PubMed]

17. Culberson, C.F.; Culberson, W.L. Chemosyndromic variation in lichens. Syst. Bot. 1976, 1, 325. [CrossRef]

18. Kealey, J.T.; Craig, J.P.; Barr, P.J. Identification of a lichen depside polyketide synthase gene by heterologous expression in Saccharomyces cerevisiae. Metab. Eng. Commun. 2021, e00172. [CrossRef] [PubMed]

19. Halvorsen, R.; Bendiksen, E. The chemical variation of Pseudevernia furfuracea in Norway. Nord. J. Bot. 1982, 2, 371-380. [CrossRef] 
20. Culberson, W.L.; Culberson, C.F.; Johnson, A. Pseudevernia furfuracea-olivetorina relationships: Chemistry and ecology. Mycologia 1977, 69, 604. [CrossRef]

21. Kosanić, M.; Manojlović, N.; Janković, S.; Stanojković, T.; Ranković, B. Evernia prunastri and Pseudoevernia furfuraceae lichens and their major metabolites as antioxidant, antimicrobial and anticancer agents. Food Chem. Toxicol. 2013, 53, 112-118. [CrossRef] [PubMed]

22. Feige, G.B.; Lumbsch, H.T.; Huneck, S.; Elix, J.A. Identification of lichen substances by a standardized high-performance liquid chromatographic method. J. Chromatogr. A 1993, 646, 417-427. [CrossRef]

23. Benatti, M.N.; Gernert, M.; Schmitt, I. Parmotrema hydrium, a new species of Parmeliaceae in southeastern Brazil. Acta Bot. Brasilica 2013, 27, 810-814. [CrossRef]

24. Cubero, O.F.; Crespo, A. Isolation of nucleic acids from lichens. In Protocols in Lichenology; Kranner, I., Beckett, R., Varma, A., Eds.; Springer: Berlin, Germany, 2002; pp. 381-391.

25. Kolmogorov, M.; Yuan, J.; Lin, Y.; Pevzner, P.A. Assembly of long, error-prone reads using repeat graphs. Nat. Biotechnol. 2019, 37, 540-546. [CrossRef]

26. Walker, B.J.; Abeel, T.; Shea, T.; Priest, M.; Abouelliel, A.; Sakthikumar, S.; Cuomo, C.A.; Zeng, Q.; Wortman, J.; Young, S.K.; et al. Pilon: An integrated tool for comprehensive microbial variant detection and genome assembly improvement. PLoS ONE 2014, 9, e112963. [CrossRef]

27. Boetzer, M.; Pirovano, W. SSPACE-LongRead: Scaffolding bacterial draft genomes using long read sequence information. BMC Bioinform. 2014, 15, 211. [CrossRef] [PubMed]

28. Huson, D.H.; Beier, S.; Flade, I.; Górska, A.; El-Hadidi, M.; Mitra, S.; Ruscheweyh, H.-J.; Tappu, R. MEGAN Community Edition Interactive exploration and analysis of large-scale microbiome sequencing data. PLoS Comput. Biol. 2016, 12, e1004957. [CrossRef]

29. Bradnam, K.R.; Fass, J.N.; Alexandrov, A.; Baranay, P.; Bechner, M.; Birol, I.; Boisvert, S.; Chapman, J.A.; Chapuis, G.; Chikhi, R.; et al. Assemblathon 2: Evaluating de novo methods of genome assembly in three vertebrate species. Gigascience 2013, 2, 10. [CrossRef]

30. Simão, F.A.; Waterhouse, R.M.; Ioannidis, P.; Kriventseva, E.V.; Zdobnov, E.M. BUSCO: Assessing genome assembly and annotation completeness with single-copy orthologs. Bioinformatics 2015, 31, 3210-3212. [CrossRef]

31. Palmer, J.; Stajich, J. Funannotate v1.7.4. Zenodo 2019.

32. Medema, M.H.; Blin, K.; Cimermancic, P.; de Jager, V.; Zakrzewski, P.; Fischbach, M.A.; Weber, T.; Takano, E.; Breitling, R. antiSMASH: Rapid identification, annotation and analysis of secondary metabolite biosynthesis gene clusters in bacterial and fungal genome sequences. Nucleic Acids Res. 2011, 39, W339-W346. [CrossRef]

33. Blin, K.; Shaw, S.; Steinke, K.; Villebro, R.; Ziemert, N.; Lee, S.Y.; Medema, M.H.; Weber, T. antiSMASH 5.0: Updates to the secondary metabolite genome mining pipeline. Nucleic Acids Res. 2019, 47, W81-W87. [CrossRef]

34. Borodovsky, M.; Lomsadze, A. Eukaryotic gene prediction using GeneMark.hmm-E and GeneMark-ES. Curr. Protoc. Bioinform. 2011, 35, 4.6.1-4.6.10. [CrossRef]

35. Quevillon, E.; Silventoinen, V.; Pillai, S.; Harte, N.; Mulder, N.; Apweiler, R.; Lopez, R. InterProScan: Protein domains identifier. Nucleic Acids Res. 2005, 33, W116. [CrossRef]

36. Huerta-Cepas, J.; Szklarczyk, D.; Heller, D.; Hernández-Plaza, A.; Forslund, S.K.; Cook, H.; Mende, D.R.; Letunic, I.; Rattei, T.; Jensen, L.J.; et al. EggNOG 5.0: A hierarchical, functionally and phylogenetically annotated orthology resource based on 5090 organisms and 2502 viruses. Nucleic Acids Res. 2019, 47, D309-D314. [CrossRef] [PubMed]

37. Huerta-Cepas, J.; Forslund, K.; Coelho, L.P.; Szklarczyk, D.; Jensen, L.J.; Von Mering, C.; Bork, P. Fast genome-wide functional annotation through orthology assignment by eggNOG-mapper. Mol. Biol. Evol. 2017, 34, 2115-2122. [CrossRef] [PubMed]

38. Almagro Armenteros, J.J.; Tsirigos, K.D.; Sønderby, C.K.; Petersen, T.N.; Winther, O.; Brunak, S.; von Heijne, G.; Nielsen, H. SignalP 5.0 improves signal peptide predictions using deep neural networks. Nat. Biotechnol. 2019, 37, 420-423. [CrossRef]

39. Käll, L.; Krogh, A.; Sonnhammer, E.L.L. Advantages of combined transmembrane topology and signal peptide prediction-the Phobius web server. Nucleic Acids Res. 2007, 35. [CrossRef] [PubMed]

40. Kautsar, S.A.; Blin, K.; Shaw, S.; Navarro-Muñoz, J.C.; Terlouw, B.R.; Van Der Hooft, J.J.J.; Van Santen, J.A.; Tracanna, V.; Suarez Duran, H.G.; Pascal Andreu, V.; et al. MIBiG 2.0: A repository for biosynthetic gene clusters of known function. Nucleic Acids Res. 2020, 48, D454-D458. [CrossRef] [PubMed]

41. Sullivan, M.J.; Petty, N.K.; Beatson, S.A. Easyfig: A genome comparison visualizer. Bioinformatics 2011, 27, 1009-1010. [CrossRef] [PubMed]

42. Shen, W.; Le, S.; Li, Y.; Hu, F. SeqKit: A cross-platform and ultrafast toolkit for FASTA/Q file manipulation. PLoS ONE 2016, 11, e0163962. [CrossRef]

43. Rice, P.; Longden, L.; Bleasby, A. EMBOSS: The European Molecular Biology Open Software Suite. Trends Genet. 2000, 16, $276-277$. [CrossRef]

44. Kjærbølling, I.; Vesth, T.C.; Frisvad, J.C.; Nybo, J.L.; Theobald, S.; Kuo, A.; Bowyer, P.; Matsuda, Y.; Mondo, S.; Lyhne, E.K.; et al. Linking secondary metabolites to gene clusters through genome sequencing of six diverse Aspergillus species. Proc. Natl. Acad. Sci. USA 2018, 115, E753-E761. [CrossRef]

45. Stamatakis, A. RAxML version 8: A tool for phylogenetic analysis and post-analysis of large phylogenies. Bioinformatics 2014, 30, 1312-1313. [CrossRef] [PubMed] 
46. Stamatakis, A. RAxML-VI-HPC: Maximum likelihood-based phylogenetic analyses with thousands of taxa and mixed models. Bioinformatics 2006, 22, 2688-2690. [CrossRef] [PubMed]

47. Miller, M.A.; Pfeiffer, W.; Schwartz, T. Creating the CIPRES Science Gateway for inference of large phylogenetic trees. In Proceedings of the Gateway Computing Environments Workshop (GCE), New Orleans, LA, USA, 14 November 2010; pp. 1-8. [CrossRef]

48. Lünne, F.; Niehaus, E.M.; Lipinski, S.; Kunigkeit, J.; Kalinina, S.A.; Humpf, H.U. Identification of the polyketide synthase PKS7 responsible for the production of lecanoric acid and ethyl lecanorate in Claviceps purpurea. Fungal Genet. Biol. 2020, $145,103481$. [CrossRef] [PubMed]

49. Pizarro, D.; Divakar, P.K.; Grewe, F.; Crespo, A.; Dal Grande, F.; Lumbsch, H.T. Genome-wide analysis of biosynthetic gene cluster reveals correlated gene loss with absence of usnic acid in lichen-forming fungi. Genome Biol. Evol. 2020, 12, 1858-1868. [CrossRef]

50. Rubio-Piña, J.A.; Zapata-Pérez, O. Isolation of total RNA from tissues rich in polyphenols and polysaccharides of mangrove plants. Electron. J. Biotechnol. 2011, 14.

51. Langmead, B.; Salzberg, S.L. Fast gapped-read alignment with Bowtie 2. Nat. Methods 2012, 9, 357-359. [CrossRef]

52. Kim, D.; Pertea, G.; Trapnell, C.; Pimentel, H.; Kelley, R.; Salzberg, S.L. TopHat2: Accurate alignment of transcriptomes in the presence of insertions, deletions and gene fusions. Genome Biol. 2013, 14, R36. [CrossRef]

53. Mortazavi, A.; Williams, B.A.; McCue, K.; Schaeffer, L.; Wold, B. Mapping and quantifying mammalian transcriptomes by RNA-Seq. Nat. Methods 2008, 5, 621-628. [CrossRef]

54. Dillies, M.A.; Rau, A.; Aubert, J.; Hennequet-Antier, C.; Jeanmougin, M.; Servant, N.; Keime, C.; Marot, N.S.; Castel, D.; Estelle, J.; et al. A comprehensive evaluation of normalization methods for Illumina high-throughput RNA sequencing data analysis. Brief. Bioinform. 2013, 14, 671-683. [CrossRef]

55. Robinson, M.D.; Oshlack, A. A scaling normalization method for differential expression analysis of RNA-seq data. Genome Biol. 2010, 11, R25. [CrossRef]

56. Oshlack, A.; Wakefield, M.J. Transcript length bias in RNA-seq data confounds systems biology. Biol. Direct 2009, 4, 14. [CrossRef]

57. Drott, M.T.; Bastos, R.W.; Rokas, A.; Ries, L.N.A.; Gabaldón, T.; Goldman, G.H.; Keller, N.P.; Greco, C. Diversity of secondary metabolism in Aspergillus nidulans clinical isolates. mSphere 2020, 5, e00156-20. [CrossRef]

58. Moore, B.D.; Andrew, R.L.; Külheim, C.; Foley, W.J. Explaining intraspecific diversity in plant secondary metabolites in an ecological context. New Phytol. 2014, 201, 733-750. [CrossRef]

59. Zhu, B.; Ibrahim, M.; Cui, Z.; Xie, G.; Jin, G.; Kube, M.; Li, B.; Zhou, X. Multi-omics analysis of niche specificity provides new insights into ecological adaptation in bacteria. ISME J. 2016, 10, 2072-2075. [CrossRef]

60. Thynne, E.; Mead, O.L.; Chooi, Y.-H.; McDonald, M.C.; Solomon, P.S. Acquisition and loss of secondary metabolites shaped the evolutionary path of three emerging phytopathogens of wheat. Genome Biol. Evol. 2019, 11, 890-905. [CrossRef] [PubMed]

61. Singh, G.; Calchera, A.; Schulz, M.; Drechsler, M.; Bode, H.B.; Schmitt, I.; Dal Grande, F. Climate-specific biosynthetic gene clusters in populations of a lichen-forming fungus. Environ. Microbiol. 2021, 23, 4260-4275. [CrossRef]

62. Wisecaver, J.H.; Slot, J.C.; Rokas, A. The Evolution of Fungal Metabolic Pathways. PLoS Genet. 2014, 10, e1004816. [CrossRef] [PubMed]

63. Lind, A.L.; Wisecaver, J.H.; Lameiras, C.; Wiemann, P.; Palmer, J.M.; Keller, N.P.; Rodrigues, F.; Goldman, G.H.; Rokas, A. Drivers of genetic diversity in secondary metabolic gene clusters within a fungal species. PLoS Biol. 2017, 15, e2003583. [CrossRef] [PubMed]

64. Rokas, A.; Wisecaver, J.H.; Lind, A.L. The birth, evolution and death of metabolic gene clusters in fungi. Nat. Rev. Microbiol. 2018, 16, 731-744. [CrossRef] [PubMed]

65. Vicente, C.M.; Thibessard, A.; Lorenzi, J.N.; Benhadj, M.; Hôtel, L.; Gacemi-Kirane, D.; Lespinet, O.; Leblond, P.; Aigle, B. Comparative genomics among closely related Streptomyces strains revealed specialized metabolite biosynthetic gene cluster diversity. Antibiotics 2018, 7, 86. [CrossRef] [PubMed]

66. Macheleidt, J.; Mattern, D.J.; Fischer, J.; Netzker, T.; Weber, J.; Schroeckh, V.; Valiante, V.; Brakhage, A.A. Regulation and role of fungal secondary metabolites. Annu. Rev. Genet. 2016, 50, 371-392. [CrossRef]

67. Keller, N.P. Fungal secondary metabolism: Regulation, function and drug discovery. Nat. Rev. Microbiol. 2019, 17, 167-180. [CrossRef]

68. Fox, E.M.; Howlett, B.J. Secondary metabolism: Regulation and role in fungal biology. Curr. Opin. Microbiol. 2008, 11, 481-487. [CrossRef]

69. Patra, B.; Schluttenhofer, C.; Wu, Y.; Pattanaik, S.; Yuan, L. Transcriptional regulation of secondary metabolite biosynthesis in plants. Biochim. Biophys. Acta Gene Regul. Mech. 2013, 1829, 1236-1247. [CrossRef]

70. Collemare, J.; Seidl, M.F. Chromatin-dependent regulation of secondary metabolite biosynthesis in fungi: Is the picture complete? FEMS Microbiol. Rev. 2019, 43, 591-607. [CrossRef]

71. Yin, W.; Keller, N.P. Transcriptional regulatory elements in fungal secondary metabolism. J. Microbiol. 2011, 49, 329-339. [CrossRef]

72. Wasil, Z.; Pahirulzaman, K.A.K.; Butts, C.; Simpson, T.J.; Lazarus, C.M.; Cox, R.J. One pathway, many compounds: Heterologous expression of a fungal biosynthetic pathway reveals its intrinsic potential for diversity. Chem. Sci. 2013, 4, 3845-3856. [CrossRef]

73. Jenni, S.; Leibundgut, M.; Maier, T.; Ban, N. Architecture of a fungal fatty acid synthase at 5 Å resolution. Science (80-.) 2006, 311, 1263-1267. [CrossRef] 
74. Watanabe, C.M.H.; Wilson, D.; Linz, J.E.; Townsend, C.A. Demonstration of the catalytic roles and evidence for the physical association of type I fatty acid synthases and a polyketide synthase in the biosynthesis of aflatoxin B1. Chem. Biol. 1996, 3, 463-469. [CrossRef]

75. Gluck-Thaler, E.; Haridas, S.; Binder, M.; Grigoriev, I.V.; Crous, P.W.; Spatafora, J.W.; Bushley, K.; Slot, J.C. The architecture of metabolism maximizes biosynthetic diversity in the largest class of fungi. Mol. Biol. Evol. 2020, 37, 2838-2856. [CrossRef] [PubMed] 